Provided for non-commercial research and education use. Not for reproduction, distribution or commercial use.

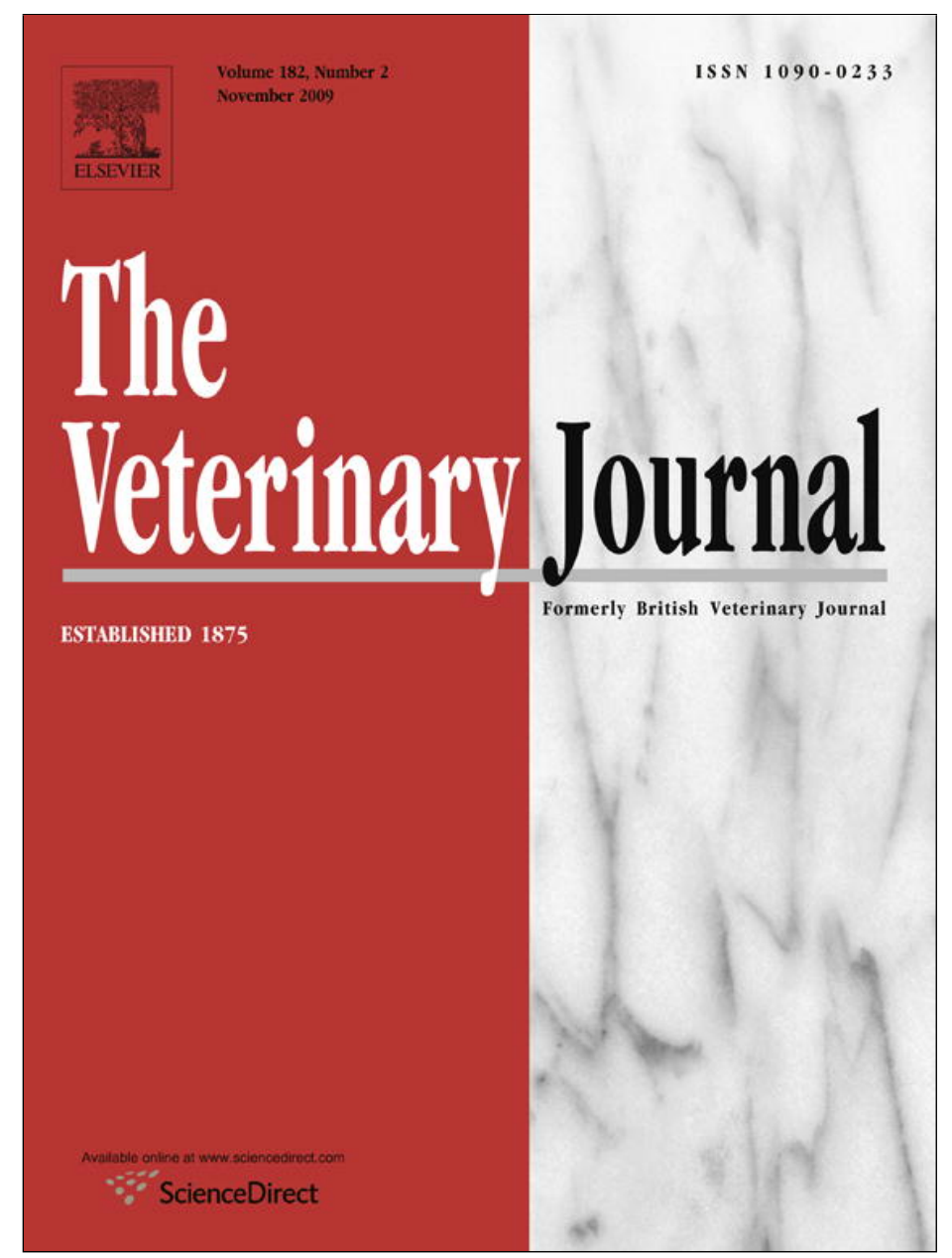

This article appeared in a journal published by Elsevier. The attached copy is furnished to the author for internal non-commercial research and education use, including for instruction at the authors institution and sharing with colleagues.

Other uses, including reproduction and distribution, or selling or licensing copies, or posting to personal, institutional or third party websites are prohibited.

In most cases authors are permitted to post their version of the article (e.g. in Word or Tex form) to their personal website or institutional repository. Authors requiring further information regarding Elsevier's archiving and manuscript policies are encouraged to visit:

http://www.elsevier.com/copyright 


\title{
A study of the prevalence and genotypes of Giardia duodenalis infecting kennelled dogs
}

\author{
Paola Scaramozzino ${ }^{\mathrm{a}}$, David Di Cave ${ }^{\mathrm{b}, \mathrm{c}}$, Federica Berrilli $^{\mathrm{b}}$, Carlo D’Orazi ${ }^{\mathrm{c}}$, \\ Alessandra Spaziani ${ }^{\mathrm{d}}$, Sabrina Mazzanti ${ }^{\mathrm{e}}$, Francesco Scholl ${ }^{\mathrm{a}}$, Claudio De Liberato ${ }^{\mathrm{a}, *}$ \\ a Istituto Zooprofilattico Sperimentale delle Regioni Lazio e Toscana, via Appia Nuova 1411, 00178 Rome, Italy

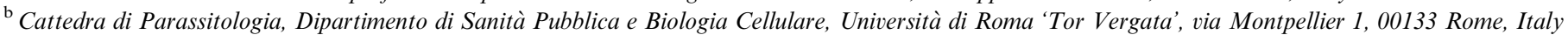 \\ ' Azienda Ospedaliera Universitaria Policlinico 'Tor Vergata', Rome, Italy \\ ${ }^{\mathrm{d}}$ Servizio Veterinario, Ospedale Veterinario ASL Roma D, via della Magliana 856, 00100 Rome, Italy \\ ${ }^{\mathrm{e}}$ Servizio Veterinario ASL Roma C, Via Monza 2, 00182 Rome, Italy
}

Accepted 8 July 2008

\begin{abstract}
Giardia duodenalis is a protozoan parasite of animals that is zoonotic. Given the capacity of this organism to spread via the faecal-oral route, animals held in overcrowded and unhygienic conditions are at high risk of infection. Faecal samples from dogs in three kennels in Rome were examined by microscopy and PCR for $G$. duodenalis, and the prevalence data generated were correlated with variables such as kennel identity, age of dog, length of time the dog had been kennelled and clinical signs.

The overall prevalence of the parasite in the faecal samples was $20.5 \%$ and was higher in samples from the largest kennel, which had the greatest turnover of dogs, and in faecal samples from younger animals. Giardia cysts were found more frequently in diarrhoeic animals but were also found in dogs with no clinical signs. Although the finding that the majority of isolates were dog-specific rather than zoonotic genotypes suggests that the zoonotic risk from this pathogen is less than previously thought, the higher prevalence of infection in younger dogs may pose a specific public health issue as such animals are more frequently re-homed with families.
\end{abstract}

(c) 2008 Elsevier Ltd. All rights reserved.

Keywords: Giardia duodenalis; Dog; Kennelling; Genotyping; Microscopy; PCR

\section{Introduction}

In 1991, legislation introduced in Italy (L 281/1991) gave local authorities responsibility for the control of stray dogs. Captured strays are now kennelled under the supervision of veterinarians and are vaccinated and given anthelmintic treatments to prevent the spread of infectious and parasitic diseases. Given the capacity of the flagellate protozoan parasite Giardia duodenalis to spread via the faecaloral route, such kennelled dogs can be at increased risk of

\footnotetext{
* Corresponding author. Tel.: +39 0679099424; fax: +390679340724.

E-mail address: claudio.deliberato@izslt.it (C. De Liberato).
}

this infection. Furthermore, some genotypes of G. duodenalis are zoonotic (Hunter and Thompson, 2005).

The prevalence of canine giardiosis worldwide varies from $5 \%$ in well cared-for domestic pets to up to $100 \%$ in kennelled animals (Barr and Bowman, 1994; Bugg et al., 1999; Barutzky and Schaper, 2003; Dubnà et al., 2007). In Italy, sheltered animals have levels of Giardia infection of between $14 \%$ and $74 \%$ compared to levels of $4-19 \%$ in domestic pets (Giangaspero et al., 2002; Capelli et al., 2003; Berrilli et al., 2004; Bianciardi et al., 2004; Papini et al., 2005; Capelli et al., 2006; Giangaspero et al., 2007). Many factors affect the prevalence of the parasite including the age of the dog, living conditions, animal density, nutritional and immune status, and the methods used to diagnose infection. 
Molecular studies have revealed that $G$. duodenalis has at least seven major genotypes or 'assemblages' designated A-G (Monis et al., 2003). Assemblages A and B have been found in a broad range of hosts including dogs and humans whereas genotypes $\mathrm{C}$ to $\mathrm{G}$ have distinct host associations and are not considered zoonotic (Monis et al., 1996; Monis et al., 1999; Hunter and Thompson, 2005). In addition to assemblages $\mathrm{A}$ and $\mathrm{B}$, genotypes $\mathrm{C}$ and $\mathrm{D}$ are also commonly found in the dog (Monis et al., 1998).

The objective of this study was to determine the prevalence and genotypes of $G$. duodenalis infecting kennelled dogs in the Rome area using both microscopy and PCR and to evaluate the associated risk factors. Such information would be useful in the context of public health and might also lead to the development of novel ways of managing such dogs so as to reduce the incidence of this infection.

\section{Materials and methods}

\section{Study procedure}

A cross-sectional study was carried out on a population of 1400 dogs from three kennels, identified as $\mathrm{K} 1, \mathrm{~K} 2$ and $\mathrm{K} 3$, in Rome. The number of animals to be tested was calculated as 124 , on the basis of an expected prevalence of $15 \%$ (Berrilli et al., 2004), with a maximum sampling error of $6 \%$ and a confidence interval (CI) of $95 \%$.

Animals were randomly faecal sampled on one occasion by a veterinarian between April 2005 and March 2006 and the samples were examined for the presence of $G$. duodenalis both by microscopy and by PCR and data relating to potentially significant variables were collected via questionnaire at the time of sampling. The questionnaire requested data in relation to kennel identity, sex of $\operatorname{dog}$, age of $\operatorname{dog}(<1$ year old or $>1$ year old), length of time the dog had been kennelled ( $0-3$ months, 3-12 months or $>12$ months), access to common shared space, whether food was wet or dry, previous treatments (product used and date), and any clinical signs including details of faecal consistency.

\section{Kennel details}

The first kennel (K1) was newly built and housed an average of 900 dogs. Groups of up to 10 dogs had access to common, clay-based paddocks and the dogs were paired in boxes with washable, smooth cement floors. The second kennel (K2) housed 250 dogs on average and the dogs were kept in boxes in pairs or threes and had daily access to a common paddock. Box and paddock surface were similar to those in $\mathrm{K} 1$. The third kennel (K3) typically housed 230 dogs but had ceased to take animals in 2003 so that animal numbers had been steadily decreasing. In this kennel individual boxes held between 2 and 7 dogs. Standards of hygiene and animal management in the three kennels were similar and at each kennel, dogs were given anthelmintic treatment on arrival and were periodically re-treated.

\section{Microscopic examination of faeces for Giardia duodenalis}

Faecal samples were examined for Giardia cysts and/or trophozoites using the wet mount Lugol's iodine staining method and the formol ethylacetate concentration technique (Ritchie, 1948; Young et al., 1979).

\section{Genotyping of Giardia duodenalis}

Genomic DNA was extracted directly from fresh or frozen faeces samples using QIAamp DNA Stool Mini Kit (Qiagen) and stored at $4{ }^{\circ} \mathrm{C}$ until molecular analysis was performed. All DNA extracts were subjected to a nested PCR to amplify a 130 bp region of the $5^{\prime}$ end of the 18 S-rRNA gene (Read et al., 2002). Sterile distilled water was included as negative control in each batch of DNA extraction and PCR reactions. Amplification products were visualised by $1 \%$ agarose gel electrophoresis stained with a solution of $6 \mu \mathrm{L} / \mathrm{mL}$ SYBR Safe DNA gel stain (Invitrogen) and visualised under ultra-violet light. PCR products were purified using a NucleoSpin Extract (Macherey-Nagel) purification kit and were sequenced. To determine the genotype of the sample, multiple alignment of sequences were obtained using ClustalW 1.8.

\section{Statistical analysis}

Data were statistically compared using the Chi-square and Fisher exact tests. Epi Info (2005) software was used to determine the Odds ratios (OR) of the associations between the various environmental and animal variables highlighted in the questionnaire and presence of Giardia organisms.

\section{Results}

Giardia duodenalis was detected by microscopy in 14 of the faecal samples (prevalence $11.0 \%, 6.2-17.8$ CI 95\%) and by PCR in 26 samples (prevalence 20.5\%; 13.8-28.5 CI 95\%). Given that the PCR detection method was more sensitive than microscopy, particularly when the level of infection was low (McGlade et al., 2003; Amar et al., 2004), only PCR detection data were used to evaluate associations with the other variables (Table 1).

There was a significant association between kennel identity and prevalence of Giardia infection $\left(\chi^{2}=18.5\right.$; $P=0.0001)$, with a higher prevalence in K1 $(46.9 \%)$ than in K2 $(10.5 \%)$ or K3 $(15.8 \%)$. Dogs housed in K1 had a much higher risk of acquiring Giardia infection than those in the other kennels (OR $=6.7 ; 2.4-19.2 \mathrm{CI} 95 \%$ ) and animals $<1$ year old had a significantly higher prevalence of infection $(46.2 \%)$ than animals $>1$ year old $(17.9 \%)$ $(\mathrm{OR}=3.9 ; 1.0-15.0 \mathrm{CI} 95 \%)$. When length of time kennelled was considered, the prevalence values for the three time categories of $0-3$ months, 3-12 months, and $>12$ months, were $25.8 \%, 66.7 \%$ and $33.3 \%$, respectively. The Fisher exact test indicated a significant difference between

Table 1

Prevalence of Giardia duodenalis infection as determined by a PCR detection method in relation to kennel identity, age of dog, length of time kennelled and clinical signs

\begin{tabular}{llrrl}
\hline & Examined & Positive & $\begin{array}{l}\text { Prevalence } \\
(95 \% \mathrm{CI})\end{array}$ \\
\hline Total number & & 127 & 26 & $20.5(12.0-25.0)$ \\
Kennel identity & $\mathrm{K} 1$ & 32 & 15 & $46.9(22.0-52.0)$ \\
& $\mathrm{K} 2$ & 76 & 8 & $10.5(4.0-18.0)$ \\
& $\mathrm{K} 3$ & 19 & 3 & $15.8(0-29.0)$ \\
Age & $>1$ year & 114 & 20 & $17.9(10.0-23.0)$ \\
Length of time & $<1$ year & 13 & 6 & $46.2(13.0-60.0)$ \\
\multicolumn{1}{c}{ kennelled } & $<3$ months & 31 & 8 & $25.8(10.6-41.0)$ \\
& 3-12 months & 9 & 6 & $66.7(36.6-95.5)$ \\
Clinical signs & Yes months & 6 & 2 & $33.3(\mathrm{ND})$ \\
& No & 22 & 13 & $59.1(25.0-60.0)$ \\
& & 105 & 13 & $12.4(5.0-18.0)$ \\
\hline
\end{tabular}

ND: not done. 
the $0-3$ month and 3-12 month categories $(P=0.03)$ and no significant differences between the remaining combinations of categories. Giardia duodenalis was detected in 13/ $22(59.1 \%)$ of diarrhoeic dogs and in 13/105 (12.4\%) samples of faeces of normal consistency indicating a significant association between the presence of infection and this clinical sign (OR $=10.2 ; 3.6-28.6 \mathrm{CI} 95 \%)$. None of the other recorded variables (sex, access to common shared space, whether food was wet or dry, previous treatments) had any significant association with the prevalence of infection.

DNA from all samples found positive by PCR was successfully sequenced. Sequence analysis revealed 8 isolates of the zoonotic assemblage A (30.7\%) and 18 of the hostspecific genotypes C (14 isolates, $53.8 \%$ ) and D (4 isolates, $15.3 \%$ ). Isolates of different genotype were not found within samples. Because of the low numbers of genotypes detected it was no possible to test for significant associations between genotype and the specified variables.

\section{Discussion}

The overall prevalence of $20.5 \%$ Giardia infection identified in this study is similar to that previously reported in Denmark (17.1\%) (Hansen et al., 2000), the former Yugoslavia (14.4\%) (Nikolic et al., 2002), Norway $(20.7 \%$ ) (Hamnes et al., 2007) and Italy (15-32.1\%) (Giangaspero et al., 2002; Capelli et al., 2003; Berrilli et al., 2004; Bianciardi et al., 2004; Capelli et al., 2006). Although Papini et al. (2005) and Szénàsi et al. (2007) found high prevalences of infection of $55.2 \%$ and $58.8 \%$ in kennelled dogs using a $G$. duodenalis-specific coproantigen ELISA, the discrepancy found by Szénàsi et al. (2007) between prevalence as determined by this method and by microscopy $(7.5 \%)$ suggests some caution should be applied in use of this diagnostic method (Cirak and Bauer, 2004; Mekaru et al., 2007).

Given that the standard of hygiene and animal management in the three kennels was similar, the higher prevalence of infection in $\mathrm{K} 1$ could be due to one or a combination of the greater number or turnover of animals and the higher proportion of young animals in this kennel. Decreasing age has previously been implicated as an important risk factor for canine giardiosis (Bugg et al., 1999; Capelli et al., 2006; Szénàsi et al., 2007) and is probably related to immunological naivety to the pathogen (Szénàsi et al., 2007). Development of immunological competence may also explain why dogs kennelled for more than 12 months had a lower prevalence of infection. As in the current study, Capelli et al. (2006) found differences in the prevalence of $G$. duodenalis infection between dogs with and without clinical signs. The presence of Giardia cysts in clinically normal animals may reflect sub-clinical infection but is significant given the capacity of these animals to transmit the infection to other dogs and to contaminate a shared environment.

Dogs can harbour both zoonotic and host-specific genotypes of $G$. duodenalis (Monis et al., 1998; Monis et al., 1999; Read et al., 2004; Thompson et al., 2007). Previous surveys in Germany (Leonhard et al., 2007) and Japan (Itagaki et al., 2005) indicate that the zoonotic genotype A occurred more commonly in domestic dogs than did dog-specific assemblages. However studies in Brazil (Souza et al., 2007) and Hungary (Szénàsi et al., 2007) found only the host-adapted genotypes C and D. In line with the results of a previous study which found $76.5 \%$ of $G$. duodenalis isolates were of assemblage C or D, $19 \%$ of assemblage A and $4 \%$ of mixed assemblage (Giangaspero et al., 2007), the majority of the isolates in the current study were the dog-specific genotypes $\mathrm{C}$ and D. Although this finding suggests that the zoonotic risk from this pathogen is perhaps less significant than previously thought, it must be remembered that the higher prevalence of infection in younger dogs may pose a specific public health issue as such animals are more frequently re-homed with families.

\section{Conclusions}

This study has identified $G$. duodenalis infection as a significant threat to the health of kennelled dogs. The prevalence of the infection may be underestimated given that it frequently occurs without concomitant clinical signs. The findings highlight the need for the regular surveillance of kennelled dogs for this parasite using specific diagnostic methods and with follow-up drug treatments and attention to kennel hygiene as appropriate.

\section{Conflict of interest statement}

None of the authors of this paper has a financial or personal relationship with other people or organisations that could inappropriately influence or bias the content of the paper.

\section{Acknowledgement}

This study was funded by a grant from the Italian Ministry of Health.

\section{References}

Amar, C.F.L., East, C., Maclure, E., McLauchlin, J., Jenkins, C., Duncanson, P., Wareing, D.R., 2004. Blinded application of microscopy, bacteriological culture, immunoassays and PCR to detect gastrointestinal pathogens from faecal samples of patients with community-acquired diarrhoea. European Journal of Clinical Microbiology and Infectious Diseases 23, 529-534.

Barr, S.C., Bowman, D.D., 1994. Giardiasis in dogs and cats. Compendium on Continuing Education for the Practicing Veterinarian 16, 603-611.

Barutzky, D., Schaper, R., 2003. Endoparasites in dogs and cats in Germany 1999-2002. Parasitology Research 90, 48-50.

Berrilli, F., Di Cave, D., De Liberato, C., Franco, A., Scaramozzino, P., Orecchia, P., 2004. Genotype characterisation of Giardia duodenalis isolates from domestic and farm animals by SSU-rRNA gene sequencing. Veterinary Parasitology 122, 193-199. 
Bianciardi, P., Papini, R., Giuliani, G., Cardini, G., 2004. Prevalence of Giardia antigen in stool samples from dogs and cats. Revue de Medicine Vétérinaire 155, 417-421.

Bugg, R.J., Robertson, I.D., Elliot, A.D., Thompson, R.C.A., 1999. Gastrointestinal parasites of urban dogs in Perth, Western Australia. The Veterinary Journal 157, 295-301.

Capelli, G., Paoletti, B., Iorio, R., Frangipane di Regalbono, A., Pietrobelli, M., Bianciardi, P., Giangaspero, A., 2003. Prevalence of Giardia spp. in dogs and humans in Northern and Central Italy. Parasitology Research 90, 154-155.

Capelli, G., Frangipane di Regalbono, A., Iorio, R., Pietrobelli, M., Paoletti, B., Giangaspero, A., 2006. Giardia species and other intestinal parasites in dogs in North-East and Central Italy. Veterinary Record $159,422-424$.

Cirak, V.Y., Bauer, C., 2004. Comparison of conventional coproscopical methods and commercial coproantigen ELISA kits for the detection of Giardia and Cryptosporidium infections in dogs and cats. Berliner und Münchener Tierärztliche Wochenschrift 117, 410-413.

Dubnà, S., Langrovà, I., Nàpravnì, J., Jankovskà, I., Vadlejch, J., Pekàr, S., Fechtner, J., 2007. The prevalence of intestinal parasites in dogs from Prague, rural areas, and shelters of the Czech Republic. Veterinary Parasitology 145, 120-128.

Giangaspero, A., Paoletti, B., Traversa, D., Iorio, R., 2002. Giardia spp. in dogs and humans in Abruzzo region (Central Italy). Parassitologia 44, 81.

Giangaspero, A., Berrilli, F., Brandonisio, O., 2007. Giardia and Cryptosporidium and public health: the epidemiological scenario from the Italian perspective. Parasitology Research 101, 1169-1182.

Hamnes, I.S., Gjerde, B.K., Robertson, L.J., 2007. A longitudinal study on the occurrence of Cryptosporidium and Giardia in dogs during their first year of life. Acta Veterinaria Scandinavica 49, 22-32.

Hansen, E.H., Nielsen, A.L., Monrad, J., Vibe Petersen, G., 2000. Giardiose hos hunde i Danmark. Dansk-Veterinaertidsskrift 83, 13-17.

Hunter, P.R., Thompson, R.C.A., 2005. The zoonotic transmission of Giardia and Cryptosporidium. International Journal for Parasitology 35, 1181-1190.

Itagaki, T., Kinoshita, S., Aoki, M., Itoh, N., Saeki, H., Sato, N., Uetsuki, J., Izumiyama, S., Yagita, K., Endo, T., 2005. Genotyping of Giardia intestinalis from domestic and wild animals in Japan using glutamate dehydrogenase gene sequencing. Veterinary Parasitology 133, 283-287.

Leonhard, S., Pfister, K., Beelitz, P., Wielinga, C., Thompson, R.C.A., 2007. The molecular characterization of Giardia from dogs in southern Germany. Veterinary Parasitology 150, 33-38.

McGlade, T.R., Robertson, I.D., Elliot, A.D., Thompson, R.C.A., 2003. High prevalence of Giardia detected in cats by PCR. Veterinary Parasitology 110, 197-205.

Mekaru, S.R., Marks, S.L., Felley, A.J., Chouicha, N., Kass, P.H., 2007. Comparison of direct immunofluorescence, immunoassays, and fecal flotation for detection of Cryptosporidium spp. and Giardia spp. in naturally exposed cats in 4 Northern California animal shelters. Journal of Veterinary Internal Medicine 21, 959-965.

Monis, P.T., Mayrhofer, G., Andrews, R.H., Homan, W.L., Limper, L., Ey, P.L., 1996. Molecular genetic analysis of Giardia intestinalis isolates at the glutamate dehydrogenase locus. Parasitology 112, 1-12.

Monis, P.T., Andrews, R.H., Mayrhofer, G., Mackrill, J., Kulda, J., Isaac-Renton, J.L., Ey, P.L., 1998. Novel lineages of Giardia intestinalis identified by genetic analysis of organism isolated from dogs in Australia. Parasitology 116, 7-19.

Monis, P.T., Andrews, R.H., Mayrhofer, G., Ey, P.L., 1999. Molecular systematics of the parasitic protozoan Giardia intestinalis. Molecular Biology and Evolution 16, 1135-1144.

Monis, P.T., Andrews, R.H., Mayrhofer, G., Ey, P.L., 2003. Genetic diversity within the morphological species Giardia intestinalis and its relationship to host origin. Infections, Genetic and Evolution 3, 29-38.

Nikolic, A., Dimitijevic, S., Djurkovic Diakovic, O., Bobic, B., Maksimovic, Mihajlovic, O., 2002. Giardiasis in dogs and cats in the Belgrade area. Acta Veterinaria Beograd 52, 43-47.

Papini, R., Gorini, G., Spaziani, A., Cardini, G., 2005. Survey on giardiosis in shelter dog populations. Veterinary Parasitology 128, 333-339.

Read, C., Walters, J., Robertson, I.D., Thompson, R.C.A., 2002. Correlation between genotype of Giardia duodenalis and diarrhoea. International Journal for Parasitology 32, 229-231.

Read, C., Monis, P.T., Thompson, R.C.A., 2004. Discrimination of all genotypes of Giardia duodenalis at the glutamate dehydrogenase locus using PCR-RFLP. Infection, Genetic and Evolution 4, 125-130.

Ritchie, L.S., 1948. An ether sedimentation technique for routine stool examination. Bulletin of the US Army Medical Department 8, 326.

Souza, S.L., Gennari, S.M., Richtzenahin, L.J., Pena, H.F., Funada, M.R., Cortez, A., Gregori, F., Soares, M., 2007. Molecular identification of Giardia duodenalis isolates from humans, dogs, cats and cattle from the state of Sao Paulo, Brazil, by sequence analysis of fragments of glutamate dehydrogenase (gdh) coding gene. Veterinary Parasitology $149,258-264$.

Szénàsi, Z., Marton, S., Kucsera, I., Tànczos, B., Horvàth, K., Orosz, E., Lukàcs, Z., Szeidemann, Z., 2007. Preliminary investigation of the prevalence and genotype distribution of Giardia intestinalis in dogs in Hungary. Parasitology Research 101, 145-152.

Thompson, R.C.A., Palmer, C.S., O'Handley, R., 2007. The public health and clinical significance of Giardia and Cryptosporidium in domestic animals. Veterinary Journal. doi:10.1016/j.tvj1.2007.09.022.

Young, K.H., Bullock, S.L., Melvin, D.M., Spruill, C.L., 1979. Ethyl acetate as a substitute for diethyl ether in the formalin-ether sedimentation technique. Journal of Clinical Microbiology 10, 852 853 . 